\title{
Analysis of EU legume value chains from the H2020 LegValue project: What insights for organic value chains? ${ }^{\text {in }}$
}

\author{
Tiana Smadja ${ }^{1, *}$ and Frédéric Muel $^{2}$ \\ 1 Terres Univia, French Oil and Protein Seed Interbranch Organization, Paris, France \\ 2 Terres Inovia, French Oil and Protein Seed Technical Institute, Grignon, France
}

Received 3 September 2020 - Accepted 20 January 2021

\begin{abstract}
This paper presents the results of a legume-based value chain analysis based on twenty-seven case studies in the H2020 LegValue project and discusses those relating to organic legume-based value chains. The analysis aims to illustrate the diversity of legume-based value chains and to discuss the conditions by which they can successfully meet the growing demand for legumes in the EU. The research is based on a qualitative survey of the value chain stakeholders in the case studies. Regarding organic legumebased value chains, the analysis reveals two types that depend on the stakeholder type at the launch of the value chain, the stakeholder's primary objective in the chain, and the organic legume species involved. The first value chain type is launched by extension services with an aim of developing the organic production of a single legume species. The second type is launched by a stakeholder (processor or collector) acting further downstream in response to market demand for several legume species. A key success factor for these value chains is the ability of the launcher to ensure close coordination along the chain. To achieve this, several means and tools have been identified: the setting-up of a value chain development project, the implementation of contracting practices, production support programmes (technical assistance, financial support), and market support programmes (information sharing, regulation, facilitators).
\end{abstract}

Keywords: value chain / legumes / organic farming / European Union / qualitative analysis

Résumé - Analyse des chaînes de valeur des légumineuses de l'UE dans le projet H2020 LegValue: quels enseignements pour les chaînes de valeur biologiques ? Cet article présente les résultats d'une analyse de chaînes de valeur de légumineuses conduite dans le projet H2020 LegValue et discute ceux qui concernent les légumineuses issues de l'agriculture biologique. L'analyse conduite illustre la diversité des chaînes de valeur de légumineuses et examine les conditions de réussite pour répondre à la demande croissante en légumineuses dans l'UE. Elle est basée sur une enquête qualitative auprès des acteurs de chaînes de valeur dans vingt-sept cas d'études. Concernant les chaînes de valeur de légumineuses issues de l'agriculture biologique, l'analyse fait ressortir deux types de chaînes de valeur, selon l'acteur au lancement de la chaîne de valeur, son objectif premier et les espèces de légumineuses concernées. Le premier type de chaîne de valeur est lancé par les services de vulgarisation dans le but premier de développer la production en agriculture biologique d'une seule espèce de légumineuse. Le second est lancé par un acteur plutôt en aval (transformateur ou collecteur) en réponse à la demande du marché pour plusieurs espèces de légumineuses. Un facteur clé de succès pour la chaîne de valeur est la capacité de l'acteur à l'initiative de son lancement à assurer une coordination étroite tout au long de celle-ci. Pour cela, plusieurs moyens et outils ont été identifiés : la définition d'un projet de développement de la chaîne de valeur, la mise en place de pratiques contractuelles, de programmes d'appui à la production (assistance technique, soutien financier) et de programmes d'appui au marché (partage d'informations, réglementation, facilitateurs).

Mots clés : chaîne de valeur / légumineuses / agriculture biologique / Union Européenne / analyse qualitative

\footnotetext{
"Contribution to the Topical Issue "Organic foods in the oil \& protein crop supply chain / Le « Bio » dans la filière oléoprotéagineuse".

*Correspondence: t.smadja@terresunivia.fr
} 


\section{Introduction}

According to the latest data, legumes ${ }^{1}$ are the fastest growing organic crop in the European Union (EU). From 2009 to 2018 , the area under organic dry pulses ${ }^{2}$ more than doubled, representing 440000 hectares in 2018 , i.e. $18.5 \%$ of the total area of dry pulses in the EU (Willer et al., 2020). The area under organic soybean cultivation in the EU was $79521 \mathrm{hec}-$ tares in 2017 , or $8.4 \%$ of the total soybean area in the EU, which is double the figure for 2012 (Agence Bio, 2019). This growing interest in the EU is driven by growing consumer demand and high societal expectations. It also reflects the efforts of European organic farmers to improve soil fertility and to become less dependent on imports of protein crops. By 2030 , although the production of organic pulses and oilseeds (including soybean) is projected to keep increasing, given that it strongly lags behind demand, insufficient domestic supply will still continue to be compensated by imports (European Commission, 2019).

It is therefore important to question the conditions for the development of organic legumes in the EU in order to reduce this dependence on imports so that European agriculture can meet the demand of European consumers. This is the purpose of the H2020 LegValue project whose overall objective is to promote the development of legumes in the EU, including organic legumes. A preliminary step is to gain a better understanding of the ways in which these crops can be developed, in all their diversity, not only in relation to the species under consideration, but also to the countries in which they are grown. Indeed, this is one of the prerequisites for contributing to the development of legumes.

This paper presents the results of a socio-economic analysis of a sample of legume value chains, including organic value chains. It sheds light on recent trends in the development of organic markets and value chains in the EU. The paper is organized as follows. The first part presents the current situation of organic legumes in the EU and the second part describes the value chain analysis conducted as part of the LegValue project. The third and final part provides and discusses the results with a focus on organic value chains.

\section{Organic legumes in the EU: production and market}

\subsection{Organic legume production}

According to the latest FiBL-IFOAM report, 7.7\% (representing 13.8 million hectares) of the total agricultural land in the EU were farmed organically in 2018 (Willer et al., 2020). Spain (16\% of the EU's organic farmland), France $(15 \%)$, Italy (14\%) and Germany (11\%) are the countries with the largest organic cultivated areas. Arable land (cereals, fresh vegetables, green fodder, dry pulses and oilseeds) and

\footnotetext{
${ }^{1}$ Legumes refers to all dry pulses (pulses, protein crops) in addition to soybean.

2 The term "pulses" includes field beans, field peas, lupines and other dry pulses (chickpeas, lentils and dry beans (dry beans include dried, shelled kidney beans "phaseolus vulgaris", both skinned and split (excl. for sowing), Comext category number 07133390.))
}

permanent grassland (pastures and meadows) constituted the largest part of organic farmland, each amounting to 6 million hectares representing $44 \%$ of organic farmland. Permanent crops (fruit trees and berries, olive groves and vineyards) corresponded to $11 \%$ of organic farmland with 1.5 million hectares. The production of cereals and green fodder accounted for about two-thirds of the organic arable land in the EU, with 2.1 million hectares dedicated to cereals and 2.3 million hectares to green fodder. The production of dry pulses covered 442000 hectares, representing almost $7 \%$ of the organic arable land in the EU, while the production of oilseeds accounted for 307000 hectares $(5 \%$ of the organic arable land in the EU). Finally, root crops and vegetables covered 212000 hectares (3.5\% of the organic arable land in the EU).

Concerning the distribution of production per country in the EU, four countries accounted for more than half of the area under organic protein crops $^{3}$ and pulses in the EU in 2017: Italy, France, Germany and Spain (Agence Bio, 2019). While organic areas more than doubled in Italy and France between 2012 and 2017, they increased by 56\% in Germany and decreased by $33 \%$ in Spain. On the other hand, the share of areas under organic protein crops and pulses is very high in a number of countries, in particular: Greece (64.3\%), Austria (57\%), Denmark (51.4\%), Italy (49.9\%), Portugal (29.2\%) and Sweden $(27.1 \%)$ for the year 2017. For soybean, France is the leader in organic soybean production in the EU, with $31 \%$ (24 870 ha) of the total organic soybean area in the EU in 2017, followed by Austria with $22 \%$ and Romania with $18 \%$ (Agence Bio, 2019).

Depending on the species, data are not always available. France is the largest producer of organic faba bean in the EU. In 2018, the French cultivated areas of organic faba bean were 17200 hectares. The organic faba bean is the most cultivated legume, partly due to its use for self-consumption and partly to its agronomical importance in systems that prohibit the use of chemical fertilizers (Agrosynergie, 2018). Regarding organic lupin, Germany is the leading producer, with 11000 hectares under cultivation in 2017. For organic pea, French areas in 2018 represented 9100 hectares. Crops of organic lentils in France represented 11530 hectares in 2018, which is an increase of $39 \%$ compared to 2017 . Finally, for organic chickpea, France is again the main producer with 7460 hectares in 2018 (+ 60\% compared to 2017) (Agence Bio, 2019).

\subsection{Organic legume market}

In 2018, the EU was the second largest organic single market, with retail sales of organic products totalling 37.3 billion euros ( 38.5 percent of global retail sales), behind the United States. The largest European market for organic products in 2018 was Germany, with retail sales of 10.9 billion euros, followed by France (9.1 billion euros), and Italy (3.5 billion euros) (Willer et al., 2020).

Regarding the consumption of organic pulses, very little data are available at EU level. However, there is undoubtedly a strong demand for organic pulses and prices are higher than for non-organic pulses (Agrosynergie, 2018). In Spain, organic sales represent $13.6 \%$ of total grain legume sales (MAPAMA,

\footnotetext{
3 "Protein crops" refers here to pea, faba bean and lupin.
} 
2016). In France, organic lentil prices are at least 25 to $30 \%$ higher than standard lentil prices and, although the organic lentil crop area has multiplied by 10 in the last three years, the current organic supply does not cover demand (Agrosynergie, 2018).

Despite an increase in the production of organic pulses in the EU in recent years, supply falls far short of demand, so that imports remain necessary. In 2018, the EU imported 105870 tonnes of organic soybean mainly from China, India and Ukraine. No data are available on imports and exports of organic pulses (Agence Bio, 2019). For organic protein crops, intra-European Union trade has been recorded: Germany, the main organic market in the EU, imports a relatively large share of its organic protein crops, particularly from Lithuania (Agence Bio, 2019). Organic faba bean is mainly used for selfconsumption on farms and there is no foreign trade for it in the EU.

In summary, the significant increase in the production of organic legumes in the EU is coupled with growing demand. It should be noted that production is not yet able to fully satisfy the demand in the EU. With the projected increased volume of organic farming in the EU by 2030, and the Farm to Fork strategy of the European Commission's Green Deal (European Commission, 2020), organic legume-based value chains will have to enhance their ability to meet demand and thus reduce the EU's dependency on imported organic legumes. To achieve this, a first step is to better understand the existing organic legume-based value chains in order to illustrate in concrete terms their diversity depending on the EU country and legume species involved, and to identify some conditions for the success of these value chains.

The next section presents a value chain analysis conducted within the H2020 LegValue project from January 2018 to June 2019. Based on twenty-seven case studies, including five organic case studies, the socio-economic analysis aims to provide insights on the features of organic legume value chains in the EU.

\section{Analysis of legume-based value chains from the H2020 LegValue project}

\subsection{Methodology}

The H2020 LegValue project (2017-2021) aims to promote the development of legume-based production systems and value chains in the EU. To improve our knowledge of the EU legume-based sector, a specific task of the project established a diagnosis of these legume-based value chains by highlighting and analysing their main features regarding value chain governance and stakeholder behaviours and strategies (Smadja et al., 2019).

\subsubsection{The case studies}

The value chain analysis is based on twenty-seven case studies defined by the project consortium (Tab. 1). Each case study corresponds to a precise legume-based value chain under the responsibility of a project partner. The case study sample covers the ten participating countries in the project (France, Germany, Italy, Portugal, United Kingdom, Switzerland,
Netherlands, Lithuania, Latvia, Denmark), and concerns seven species of grain and fodder legume (pea, faba bean, chickpea, lentil, soybean, alfalfa and lupin).

Faba bean is the most represented species (with seven case studies), followed by pea (with six case studies) and soybean (with five case studies). Two case studies deal with chickpeas, two with lentils, one with alfalfa and one with lupins. In the latter three case studies, the actors do not specialize in a single species, but rather in a mix of legumes called "mixed species". Since these value chains have in common that they focus exclusively on organic farming, these case studies are associated with organic value chains.

In total, five case studies focus exclusively on legumes produced by organic farming. In addition to the three mixed species mentioned above, two other case studies grow faba bean and soybean using organic farming. Five case studies are dedicated to both organic and conventional activities: chickpeas, peas, alfalfa and lentils. Finally, seventeen case studies are associated with a conventional farming system. They concern chickpeas, lupins, faba beans, peas and soybeans.

\subsubsection{Focus on the five case studies concerning organic legume value chains}

The first case study (called AC1 in the case study list) relates to an organic legume value chain launched in 2010 by Nutrinat, a French company specialising in organic food and based in the Occitanie region. The legume species that it deals with are lentils, chickpeas, yellow peas and faba beans. Nutrinat collaborates with the Cooperative Group Qualisol to ensure most of its supply of organic legumes. In total, 2500 farmers and 60000 ha were potentially involved in this value chain with a regional dimension in 2018. The grain legumes collected are cooked to prepare hot dishes or salads, or processed into $100 \%$ vegetable pasta from legumes.

The second case study (called SU2) deals with an organic grain legume value chain in Tuscany (Italy), mainly concerning chickpeas and lentils. The value chain was launched in 2012 by a farmers' network to face the increasing demand for organic and local products. The network is composed of eight farms of different sizes (25-350 ha) that organically grow cereals and legumes and supply a niche market serving local consumers. The Floriddia farm is the network leader and owns most of the processing facilities: the products coming from the other farms are purchased, processed, and sold by Floriddia directly to local consumers, local shops, and restaurants.

The third case study (called TU5) focuses on an organic grain legume value chain launched in 2000 by the French Cooperative Group CAVAC. The legume species involved are pea, faba bean, soybean, lentil, and chickpea. CAVAC is based in the Northwest of France (mainly Pays de la Loire) and makes the link between farmers and end users. Its target is to develop an organic legume-based value chain to reduce imports of organic animal feed and human food. A potential 400 farmers are involved in the value chain and around 2500 tonnes of organic legumes were collected in 2017.

The fourth case study (called FI1) is an organic soybean value chain in Switzerland (Swiss Plateau, Eastern and 
Table 1. List of case studies in the H2020 LegValue project.

\begin{tabular}{|c|c|c|}
\hline $\begin{array}{l}\text { Case } \\
\text { study }\end{array}$ & Case study description & Country-legume species \\
\hline AC1 & Organic legume value chain with Nutrinat (Occitanie, France) & France-mixed species \\
\hline TU5 & Development of organic legume value chain at a regional scale (Vendée, France) & France-mixed species \\
\hline FI1 & Development of organic soya value chain (Central Plateau, Switzerland) & Switzerland-soybean \\
\hline LF2 & Faba bean organic value chain (Denmark) & Denmark-faba bean \\
\hline CR4 & $\begin{array}{l}\text { Improving the farms' performance with winter pea in crop rotation cycle } \\
\text { (Normandy, France) }\end{array}$ & France-pea \\
\hline CR5 & Development of soybean in short value chain (Charente, France) & France-soybean \\
\hline CR6 & Development of the chickpea value chain (Hérault, France) & France-chickpea \\
\hline FH1 & Development of regional faba bean value chain (Lower Saxony, Germany) & Germany-faba bean \\
\hline FH2 & Processing conventional produced pea in a regional environment (Eastern Germany) & Germany-pea \\
\hline PG2 & Vining pea for frozen processed market (Eastern England, United Kingdom) & UK-pea \\
\hline PG3 & Value chain for field bean with Frontier Agriculture Ltd (United Kingdom) & UK-fababean \\
\hline SU1 & Lentil value chain based on the GI "Lenticchia di Altamuraâ" (Alta Murgia, Italy) & Italy-lentil \\
\hline TE1 & Lupin value chain for feed at a regional scale (Pays-de-Loire, France) & France-lupin \\
\hline TE3 & Dried alfalfa value chain (France) & France-alfalfa \\
\hline TU1 & Faba bean value chain for feed with Valorex (France) & France-faba bean \\
\hline TU2 & Dehulled faba bean value chain for feeding fish (West and North of France) & France-faba bean \\
\hline TU3 & Pea ingredients value chain at a regional scale (North East of France) & France-pea \\
\hline TU4 & $\begin{array}{l}\text { Non-GMO soya value chain for feed at a regional scale } \\
\text { (Bourgogne Franche-Comté, France) }\end{array}$ & France-soybean \\
\hline
\end{tabular}

Western Switzerland). It was launched by the Research Institute of Organic Agriculture (FiBL) in 2016 with the aim of developing the whole Bio Soja value chain, from developing new varieties to applying best practices in processing soybean for feed and food purposes. In 2018, 65 farmers growing soybean in 150 hectares were involved in the value chain. Furthermore, some downstream actors (Mill Rytz, Agroscope, Delley-Semences, Progana) work closely with FiBL to create stable framework conditions for all parties involved with Swiss organic soybean.

Finally, the fifth and last case study (called LF2) explores the organic faba bean value chain in Denmark. Faba bean is considered as a new grain legume whose interest was initiated by the project Økoprotein (2012-2015). The goal of the Økoprotein project was to reduce imports of soybean and substitute them with Danish-grown grain legumes, namely faba bean and blue lupin. It was documented though organic trials that showed that growing and feeding animals (cows and pigs) with Danish-produced faba beans provided a relevant alternative to imported soybean. The area planted with organic faba bean increased from 477 ha in 2011 to 6087 ha in 2017 . The research and development institute SEGES which led the project launched the organic faba bean value chain with farmers. Since then, the growing area and use of faba beans has increased and spread to conventional farming to meet the demand of the feed industry.

\subsubsection{The data}

Data used for the diagnosis of legume-based VCs come from the twenty-seven case studies according to two sources.

First, in the constitution of the case studies, general and qualitative information on the corresponding value chains was collected. This information was gathered to characterize the value chains based on the following ten variables (see Tab. 2): the country, legume species characterizing the value chain (VC); the legume type (grain or forage legume); the geographical area of production (local/regional/national); the end-use type at the VC level (feed/food/feed-food/non-food); the farming system type (conventional or organic farming); the launcher of the VC (processor/farmer/collector-trader/extension services); the launching date of the $\mathrm{VC}$; the key actor of the $\mathrm{VC}$; and the main production outlet (self-consumption/ sales/self-consumption and sales). 


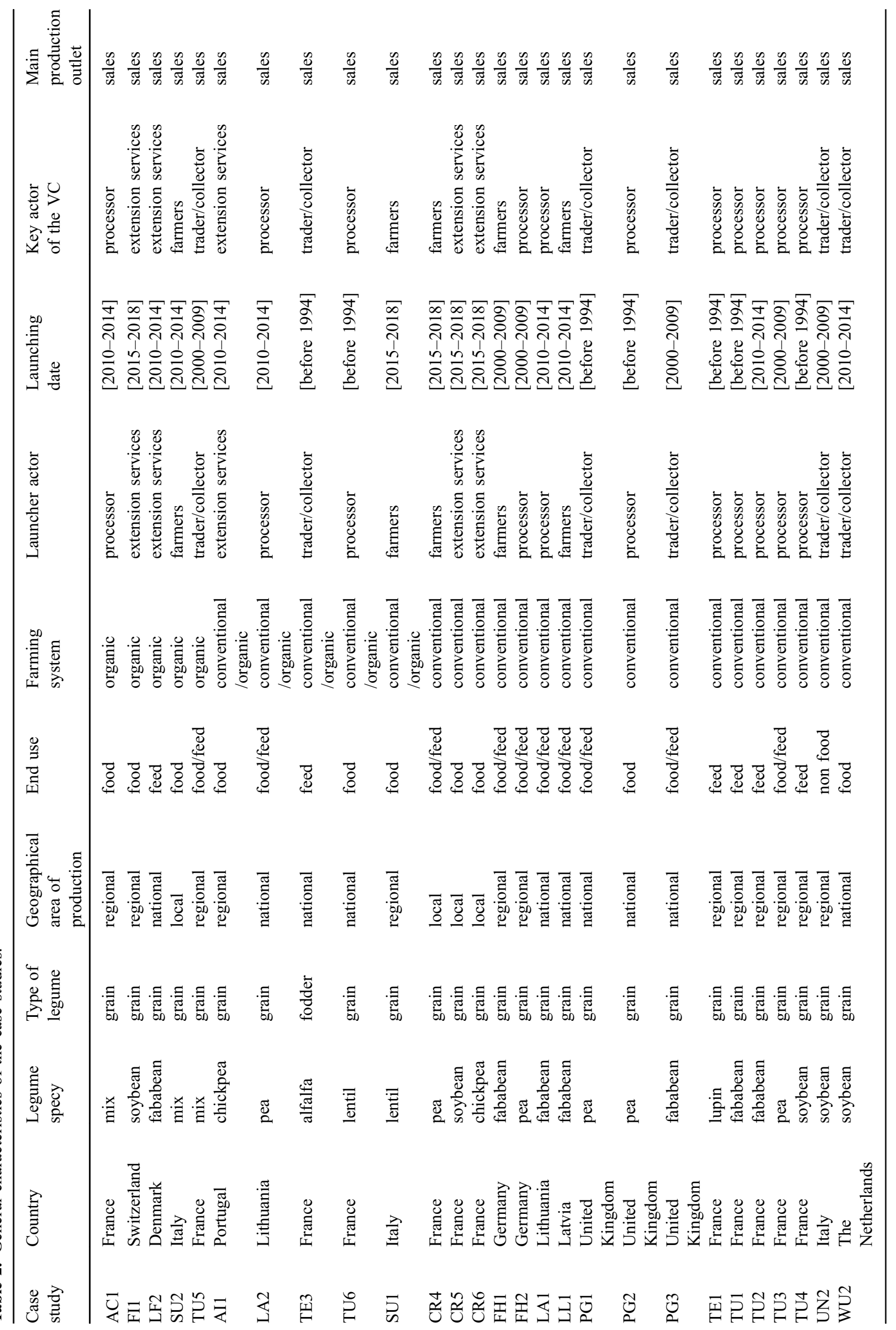


Table 3. Survey themes and content.

\begin{tabular}{ll}
\hline Thematic & Content \\
\hline General information/perceptions & Organisation size/subsidiary or not/creation date/other legumes activities/organic or not \\
of the actors & VC size/perception of markets, VCs, public policies functioning/VC leader/quality referential/ \\
& importance of legume activity in their overall activities/motivations for legume activities/ \\
& ecosystem services knowledge \\
& Barriers and levers to the development of legume activities/legume communication support/ \\
sharing of information on legumes/sharing of know-how on legumes/skills needed to develop & legumes/legume development strategy
\end{tabular}

Institutional dimension of legumes activities

Technical dimension of legumes activities

Organizational dimension of legumes activities
Recipient of public support/origin of public support/regulatory framework on legumes/
professional organisation member/collective initiative member

Processing type/co-products valorisation strategy

Reasons for legume cultivation/reason for rotation/level of know- how concerning legumes/ use of certified seed/legume yields stability/criteria for harvesting/storage of harvested product/cleaning of harvested product/destination of harvested product

Partner type in the exchanges/collaboration period/use of trader- broker/purchase and sales price determinants/reference prices and production levels/quality requirements/quality referential

Contractualization/upstream and downstream contractualization frequency/partner type in the contract/contract establishment period/contract modalities/price in the contract/quality premium Import/Export Competition level in the legume supply and processed products sale at the regional, national and international levels.
Secondly, a survey was conducted during the first half of 2018 among 127 stakeholders in these value chains from the twenty-seven case studies. Stakeholders were identified according to their organizations in the associated value chains: legume producer, collector, processor, trader/broker, input supplier, seed producer, and technical adviser. They were questioned according to their main functions within the legume-based value chains to which they belonged. The questionnaire was divided into several parts: general information on the surveyed organization and its legume activities; the institutional environment in which the surveyed organization operates; the overall functioning of the value chain in which the surveyed organization operates; the overall context of legume activities; the technological dimension of the legume activities; and finally the organizational dimension of the legume activities (see Tab. 3).

\subsubsection{Multidimensional factorial analysis}

To better assess the diversity of value chains in our case studies, a multidimensional factorial analysis of their characteristics was carried out. More precisely, we conducted a Multiple Correspondence Analysis (MCA) and an Ascending Hierarchical Classification (AHC) using the RStudio software (Husson and Josse, 2014). MCA highlights similarities between value chains and between value chain characteristics, providing an overview of these similarities. Once the results of the MCA are obtained, a classification analysis (here, the hierarchical bottom-up classification by AHC) leads to define a value chain typology (Husson et al., 2017). Indeed, it allows similar value chains to be grouped together according to criteria defined by a set of variables.

To do this, each value chain is defined by thirty variables obtained from three different sources. In addition to the variables obtained from general information on the case study, two other groups of variables come from the stakeholder survey: variables either taken directly from the survey or derived from a calculation on survey variables. These thirty variables cover five themes: overall characteristics, geographical value chain dimension, overall perceptions of stakeholders, institutional dimension, and governance or organizational issues (see Tab. 4).

- The overall characteristics of a value chain include the country of the value chain, the associated legume species, the end-use type (food/feed/non-food), the legume farming system (conventional/organic), the VC launching date, the importance level of legume activities for the actors compared to their overall activities, and their overall ecosystem services knowledge level.

- The geographical dimension of a value chain concerns the geographical production area of the associated legume crop, the spatial extent of the value chain according to the surveyed actors, the presence of import or export activities within the value chain, and finally, the comparison between the geographical extent of the value chain and the geographical area of production.

- The stakeholders' perceptions relate to their degree of satisfaction with the functioning of legume-based value chains and markets, their links with the VC leader, and 
Table 4. The thirty variables used for the value chain analysis.

\begin{tabular}{lll}
\hline Information category & Information detail & Information source \\
\hline & Country & CS responsible \\
& Legume species & CS responsible \\
General characteristics & End use & CS responsible \\
of the VC & Launching date & CS responsible \\
& Relative importance of legumes activities & All interviewed stakeholders \\
& Ecosystemic services knowledge & All interviewed stakeholders \\
& Geographical area of production & CS responsible \\
& VC spacial dimension & All interviewed stakeholder \\
Geographical concern & Legumes importation in the VC? & Interviewed processors, collectors, traders \\
& Legumes exportation in the VC? & Interviewed processors, collectors, traders \\
& VC spacial dimension larger than geographical are of & Calculated variable
\end{tabular}

\section{production?}

Balanced link with the VC leader (according to the majority of the VC (interviewed) stakeholders)?

$\mathrm{VC}$ functioning perceptions according to the majority of the VC (interviewed) stakeholders?

Legumes markets functioning perceptions according to the majority of the VC (interviewed) stakeholders?

Public policies on legumes perceptions according to the majority of the VC (interviewed) stakeholders?

Perceptions

Policies

Structure/Governance Information on legumes sharing in the $\mathrm{VC}$ according to the majority of the VC (interviewed) stakeholders? Knowledge on legumes sharing in the $\mathrm{VC}$ according to the majority of the VC (interviewed) stakeholders?

Information and knowledge on legumes sharing in the $\mathrm{VC}$ according to the majority of the VC (interviewed) stakeholders?

General perceptions about the $\mathrm{VC}$ according to the majority of the VC (interviewed) stakeholders?

Public support for the majority of the VC (interviewed) stakeholders?

Reglementary framework for legumes activities? Collective initiative member for the majority of the VC (interviewed) stakeholders?

Launcher actor of the VC

Use of more than $80 \%$ of certified seeds use by the farmers?

Dealing with trader for legumes procurement?

Dealing with trader for legumes product selling?

Quality referential along the VC?

Professional Organisation members for the majority of the VC (interviewed) stakeholders?

Production contract?

Contract between collectors and processors

Contract along the VC?

Dealing with trader for legumes procurement or for legumes selling?
All interviewed stakeholder

All interviewed stakeholder

All interviewed stakeholder

All interviewed stakeholder

All interviewed stakeholder

All interviewed stakeholder

Calculated variable

Calculated variable

\section{All interviewed stakeholder}

All interviewed stakeholder
All interviewed stakeholder

CS responsible

Interviewed farmers

Interviewed processors, collectors, traders Interviewed processors, collectors, traders All interviewed stakeholder

All interviewed stakeholder

Calculated variable

Calculated variable

Calculated variable

Calculated variable public policies on legumes. They were also asked about their perceptions of the level of efficiency of information and knowledge-sharing about legumes along their value chains. The information attributed to each value chain concerning these perceptions reflects the views of most of the interviewed stakeholders.

- The institutional and political dimension of a value chain concerns public support, regulatory frameworks specific to legumes, as well as collective initiatives that can support the activities of actors in a value chain and their membership in professional organizations.

- The value chain governance affects the relationships between actors from upstream to downstream. The associated variables are the value chain launcher, the use or not of traders in the supply of legumes and also in the sale of processed products, the existence of a quality reference framework along the value chain, and finally, the existence of upstream contracts involving farmers, 


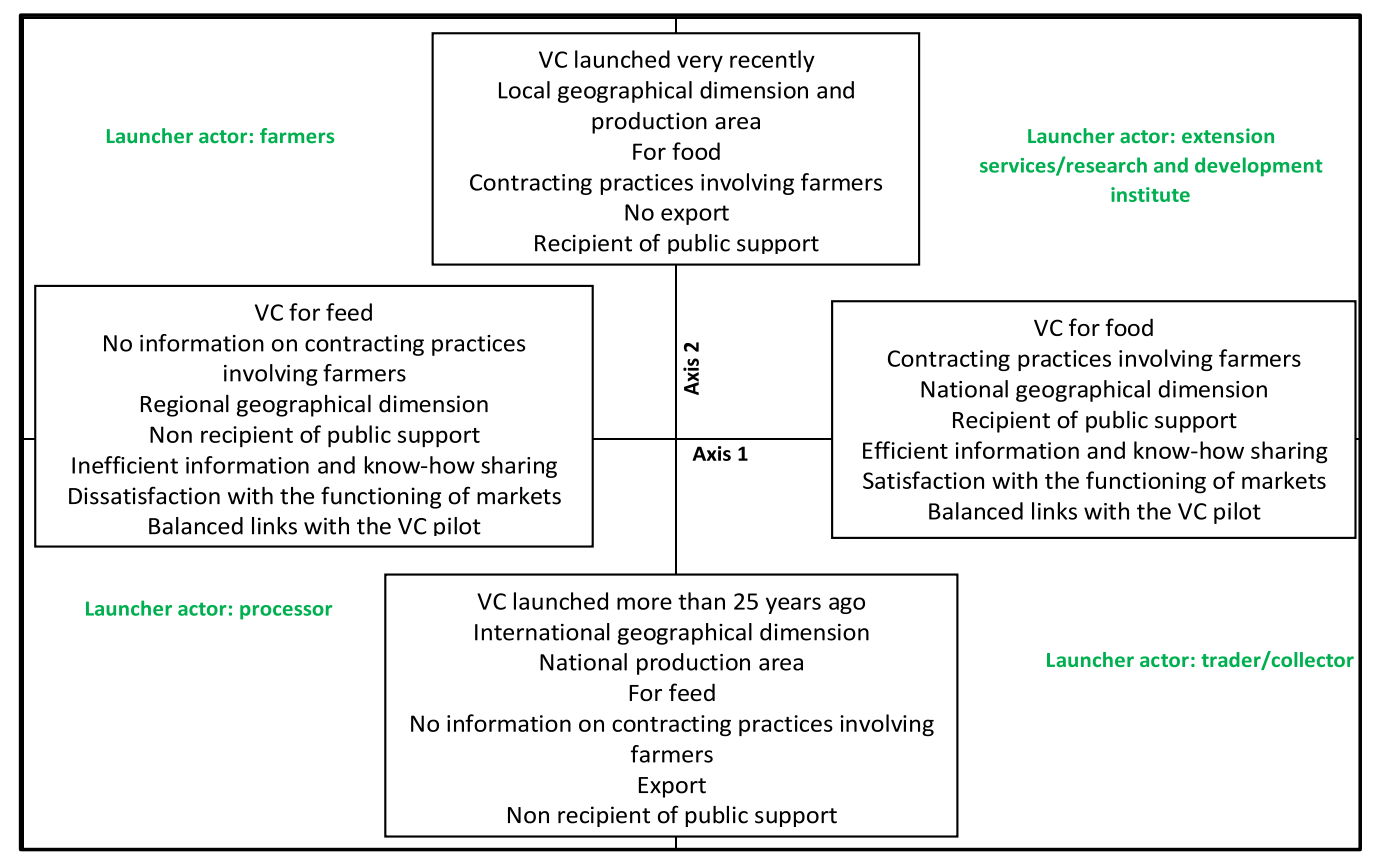

Fig. 1. Factor space from the MCA.

collectors, processors and downstream contracts involving processors, collectors, retailers and traders in particular.

\section{Results and discussions}

\subsection{Overall results of the Multiple Correspondence Analysis (MCA)}

The Multiple Correspondence Analysis (MCA) of these data provides the factor space on which the case studies will graphically be represented according to their similarities and differences (Fig. 1). The factor space itself is constructed along a horizontal axis (axis 1) and a vertical axis (axis 2) defined from the thirty variables mobilized in the MCA.

Axis 1 pits value chains dedicated to feed against those dedicated to food; those with no information on contracting practice between farmers and buyers of their products against those with confirmed contracting practice; those where most actors do not receive public support against those where most actors do receive public support; those with a regional $\mathrm{VC}$ dimension against those with a national VC dimension; those where most actors are dissatisfied with the way legume markets operate against those where most actors are satisfied; those where legume knowledge and information-sharing is considered inefficient by the actors against those where it is considered efficient; and those where the actors are mostly satisfied with their relationship with the actor they consider to be the VC leader against those where the actors are mostly dissatisfied.

Axis 2 pits value chains dedicated to feed against those dedicated to food; those with no information on contracting practice between farmers and buyers of their products against those with a confirmed contracting practice; those where most actors do not receive public support against those where most actors benefit; those where most farmers use certified seed against those where most do not use it; those with an international VC dimension against those with a local VC dimension; those associated with a national geographical production area against those associated with a local geographical area; those launched before 1994 against those launched after 2014; and finally, those developing export activities against those that are not.

In summary, some typical profiles can be defined at the extremity of both the horizontal and vertical axes. It is also interesting to note that each of the four modalities of the illustrative 4 variable "actor initiating the launch of the value chain" is in a well-defined quadrant, as shown in green in Figure 1. In other words, value chains are grouped into a well-defined quadrant according to the actor initiating their launch: those launched by farmers are located in the top left quadrant, those launched by extension services in the top right quadrant, those launched by traders or collectors in the bottom right quadrant, and those launched by processors in the bottom left quadrant. Regarding organic farming, it seems that this is not a discriminating factor for the case studies.

The projections of the different case studies in the factor space defined by the MCA shows that the different value chains are distributed in a balanced way throughout the factorial space (Fig. 2). This indicates that they are truly diverse. A similar observation is made for the organic case studies (circled in red in Fig. 2). The main differences between them will be highlighted later.

\footnotetext{
${ }^{4}$ The illustrative variable entitled "actor initiating the launch of the value chain" does not contribute to define the two axes.
} 


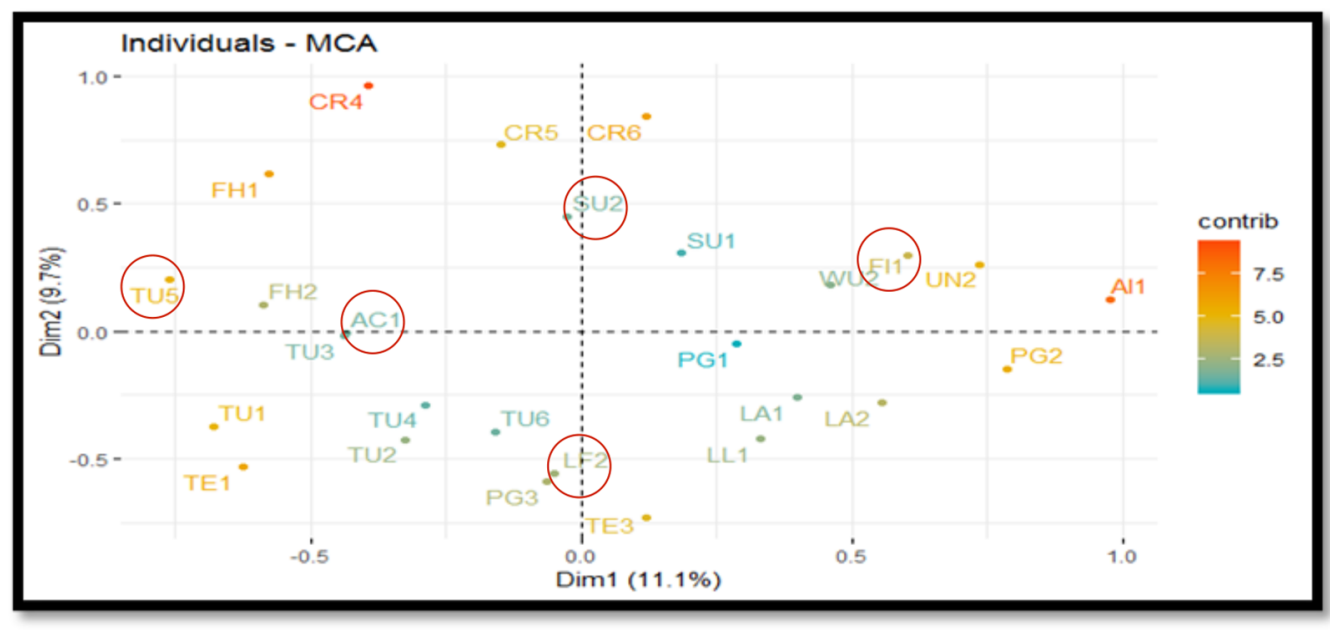

Fig. 2. Distribution of case studies in the MCA factor space.

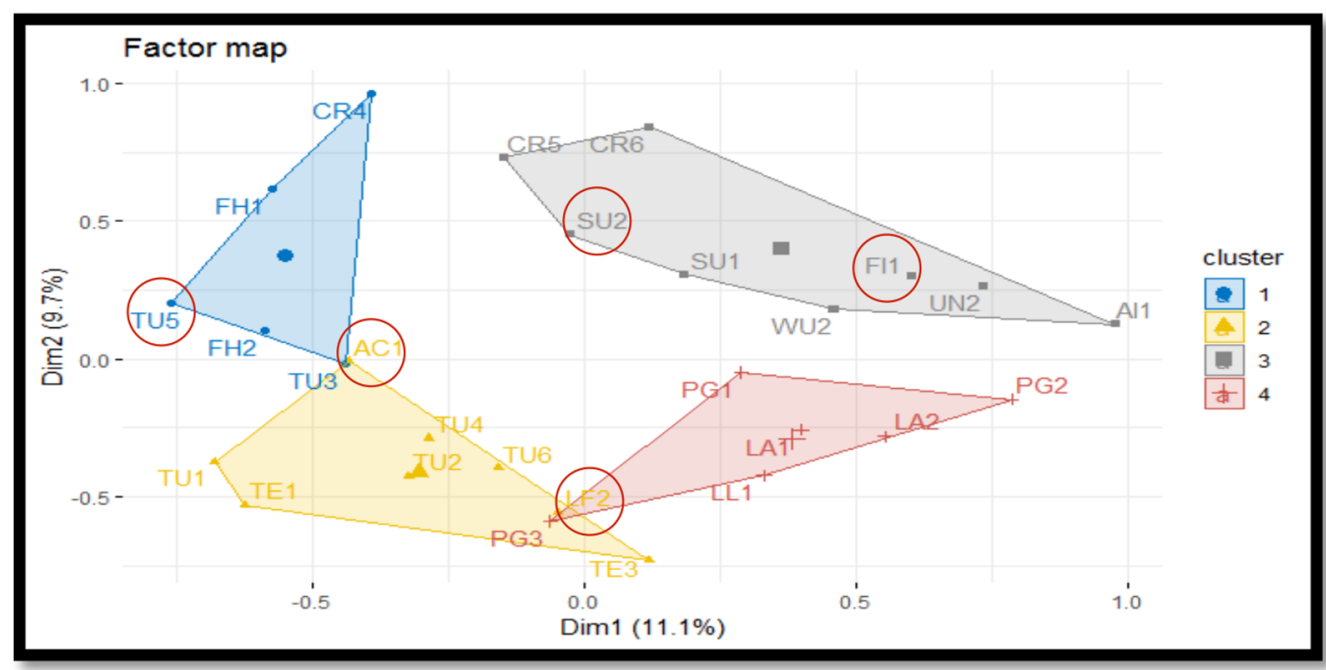

Fig. 3. Distribution of case studies into four classes according to the HAC.

\subsection{Results of the Hierarchical Ascending Classification (HAC)}

The hierarchical ascending (bottom-up) classification (HAC) on case study data is a statistical technique that allows the case studies to be divided into classes, so that the case studies classified within the same class are as similar as possible (intra-class homogeneity) and the classes in different classes are as dissimilar as possible (inter-class heterogeneity). Classification is ascending (bottom-up) because it starts from individual data, and hierarchical because it produces increasingly large classes that include subclasses. From the results of the MCA, the hierarchical ascending (bottom-up) classification (HAC) determines case study classes from our sample based on similarities in clearly identified modalities. As a result, the HAC emphasizes a division of case studies into four classes (Fig. 3).

According to the statistical results, the four classes are mainly defined by two variables: the legumes' end-use, and the stakeholder's perceptions on the value chain functioning. In other words, these two variables are the first elements that distinguish classes from each other. More generally, the table below gives an overview of the modalities that contribute to the definition of these different classes from the statistical results (see Tab. 5).

- The first class (named C1) includes value chains for both food and feed, with inefficient information-sharing

The five value chains (CR4, FH1, FH2, TU3, TU5) of this class have in common that they focus on both food and feed. They concern France and Germany and were mainly launched in the early 2000s. Three value chains deal with peas, one with faba beans and one with a mixed species. The value chains belonging to this first class are characterized by links that are considered unbalanced between the leaders of these chains and the other actors. Information-sharing is also considered inefficient. 
Table 5. Main modalities characterizing the four classes.

\begin{tabular}{|c|c|c|c|}
\hline \multicolumn{2}{|c|}{ ClassMain characteristics } & \multirow{2}{*}{$\begin{array}{l}\text { Case studies involved } \\
\text { FH1 Germany-faba bean } \\
\text { FH2 Germany-pea } \\
\text { CR4 France-pea } \\
\text { TU3 France-pea } \\
\text { TU5 France-mix }\end{array}$} & \multirow{2}{*}{$\begin{array}{l}\text { Value chain } \\
\text { type } \\
\begin{array}{l}\text { VC both for feed and food with inefficient information } \\
\text { sharing }\end{array}\end{array}$} \\
\hline 1 & $\begin{array}{l}\text {-with inefficient information sharing } \\
\text {-both for food and feed } \\
\text { - unbalanced links with the VC leader } \\
\text { essentially: } \\
\text {-launched between } 2000 \text { and } 2009 \\
\text {-different perceptions of VC functioning }\end{array}$ & & \\
\hline 2 & $\begin{array}{l}\text {-no information on contract involving farmer } \\
\text {-non-majority use of certified seed } \\
\text {-export } \\
\text { essentially: } \\
\text {-in France } \\
\text {-non recipient of public support } \\
\text { - dissatisfaction with markets functioning } \\
\text {-launched by transformers } \\
\text {-mainly for feed }\end{array}$ & $\begin{array}{l}\text { sTU6 France-lentil } \\
\text { TE1 France-lupin } \\
\text { TU1 France-faba bean } \\
\text { TU2 France-faba bean } \\
\text { TU4 France-soybean } \\
\text { AC1 France-mix } \\
\text { TE3 France-alfalfa } \\
\text { LF2 Denmark-faba bean }\end{array}$ & $\begin{array}{l}\text { VC often for feed, with dissatisfaction with markets } \\
\text { functioning }\end{array}$ \\
\hline 3 & $\begin{array}{l}\text { essentially: } \\
\text {-for food } \\
\text {-with efficient information sharing } \\
\text {-recipient of public support }\end{array}$ & $\begin{array}{l}\text { SU2 Italy-mix } \\
\text { SU1 Italy-lentil } \\
\text { AI1 Portugal-chickpea } \\
\text { FI1 Switzerland-soybean } \\
\text { UN2 Italy-soybean } \\
\text { WU2The Netherlands-soybean } \\
\text { CR5 France-soybean } \\
\text { CR6 France-chickpea }\end{array}$ & VC for food, with efficient information sharing \\
\hline 4 & $\begin{array}{l}\text {-geographical production area: national } \\
\text {-positive perceptions of markets functioning } \\
\text { essentially: } \\
\text {-both for food and feed }\end{array}$ & $\begin{array}{l}\text { PG3 UK-faba bean } \\
\text { PG1 UK-pea } \\
\text { PG2 UK-pea } \\
\text { LL1 Latvia-faba bean } \\
\text { LA1 Lithuania-faba bean } \\
\text { LA2 Lithuania-pea }\end{array}$ & $\begin{array}{l}\text { VC both for food and feed, with satisfaction with } \\
\text { markets functioning }\end{array}$ \\
\hline
\end{tabular}

- The second class (named C2) includes the value chains most often dedicated to feed, featuring stakeholder dissatisfaction with the way the markets function

Most often dedicated to feed, with the exception of TU6 (lentil value chain in France) and AC1 (mixed species value chain in France), the eight value chains (AC1, LF2, TE1, TE3, TU1, TU2, TU4, TU6) in this class were most often launched by processors, with the exception of LF2 (launched by a research and development institute) and TE3 (launched by collectors). They are almost all located in France, except for LF2 located in Denmark, and they concern various legume species, except pea: lentil, lupin, faba bean, soybean, alfalfa and a mixed species. Collected information on contractualization in value chains of this class most often involves collectors and processors. In addition, all these value chains develop export activities.

- The third class (named C3) includes value chains most often dedicated to food, and with efficient informationsharing between stakeholders

The eight value chains in this class (SU2, SU1, AI1, FI1, UN2, WU2, CR5, CR6) have in common that they are all dedicated to human consumption, with the exception of value chain UN2 (soybean sector for biofuel production in Italy). They cover different countries and different legume species, the main one being soybean (in France, the Netherlands, Italy and Switzerland), followed by chickpea (in Portugal and France), lentil (in Italy) and mixed species (in Italy). Half of them were initiated by extension services. The other half were initiated by farmers or collectors. According to the stakeholders interviewed in these value chains, there is efficient information-sharing along them. In addition, all value chains in this class receive public support.

- The fourth class (named C4) includes value chains for both food and feed, and features stakeholder satisfaction with the functioning of markets

The six value chains in this class (PG3, PG1, PG2, LL1, LA1, LA2) are all dedicated to both food and feed, except the PG2 value chain which is exclusively dedicated to food. Half of them concern peas and the other half concern faba beans. This class includes value chains in the United Kingdom and the Baltic States (Latvia and Lithuania). Most of the actors surveyed in these value chains were satisfied with the way the markets functioned. In addition, the supply area associated with these 
value chains is the entire territory at the level of the concerned countries.

Regarding the five organic value chains, they are diversely spread over the four classes of the value chain typology. While the value chains in the AC1 and LF2 case studies belong to the C2 class, those in the SU2 and LF1 case studies are part of the C3 class. The last organic value chain in the TU5 case study belongs to the $\mathrm{C} 1$ class.

\subsection{Discussion}

The multidimensional analysis of the overall characteristics of the case studies gives an illustration of the diversity of the legume-based value chains analysed in the H2020 LegValue project. It also reveals some interesting elements to understand the historical evolution of legume-based value chains, and hence the entire legume sector in the EU. Finally, some insights into organic legume value chains can be highlighted.

\subsubsection{Distinction between recent food value chains and historical feed value chains}

The oldest value chains in our sample were launched before 1994, mainly by processors, belong to the C2 class and are dedicated to feed. The most recent ones, which belong to the $\mathrm{C} 3$ class, were most often launched in the last four years by extension services and are devoted to human consumption. These two classes are distinguished by opposing stakeholder perceptions of their overall functioning. Indeed, actors in the C2 value chains feel dissatisfied with the way the markets function, while those in the $\mathrm{C} 3$ class consider that informationsharing is efficient between actors. While farmers are often involved in contracting practices in the $\mathrm{C} 3$ class, in the $\mathrm{C} 2$ class, contracting practices most often concern collectors and processors. Finally, in terms of legume species, the value chains for food are dedicated to chickpeas, lentils, peas and soybeans, while those for feed are dedicated to faba beans, soybeans and alfalfa. The mixed species is devoted to both food and feed.

The difference between these two classes illustrates first of all the recent and growing emergence of an interest in legumes in the food market (as represented by the $\mathrm{C} 3$ value chain class) in the EU, where historically legumes were overwhelmingly devoted to feed (Zander et al., 2016; Magrini et al., 2016). The importance of contracting practices involving farmers in value chains for food (Cholez, 2019), the crucial role of technical and extension services in launching value chains, and the efficient information-sharing perception shared by stakeholders can be interpreted as a collective willingness to optimally govern the value chain. In the $\mathrm{C} 2$ value chain class, the lack of information on contracting practices involving farmers, as well as the stakeholders' dissatisfaction with the markets' functioning, could point to weak coordination along the value chains, which could constitute a barrier to the development of the latter (Meynard et al., 2013).

\subsubsection{Opposition between two types of value chain dealing with peas and faba beans}

After soybean, pea and faba bean are the two most cultivated legume species in the EU. While they were historically dedicated to animal feed (due to the Common Agricultural Policy's support of these crops for feed in the 1980s), there has been a growing demand for these two legume species for human food in recent years (Voisin et al., 2014). Thanks to their high protein content, peas are subject to increasing interest from the food processing industry dedicated to producing plant-based meat alternatives, while faba beans are exported to the Middle East and North Africa where they are a staple in the population's diet (Kezeya et al., 2020). Another growing use of the faba bean in the last few years is for fish feed in Norway.

The value chains belonging to the two other classes $(\mathrm{C} 1$ and $\mathrm{C} 4$ ) of the value chain typology all deal with peas or faba beans, except a value chain in the $\mathrm{C} 1$ class that concerns organic legumes. Contrary to the value chains in the $\mathrm{C} 2$ and $\mathrm{C} 3$ classes, each value chain belonging to the $\mathrm{C} 1$ and $\mathrm{C} 4$ classes is dedicated to both feed and food. This is in line with the possibility for peas and faba beans to meet food and feed demand, as mentioned above. Depending on the production or market opportunities, stakeholders target peas and faba beans to one of the two potential outlets.

Through these two classes, the value chain typology highlights two distinct ways to deal with peas and faba beans. In the $\mathrm{C} 1$ class, peas and faba beans are primarily used as food ingredients by the processing industry. The corresponding value chains are piloted by these processors. They are based in France and Germany, and they develop import activities. Regarding stakeholders' perceptions of the value chains' functioning, these value chains are marked by inefficient information-sharing between stakeholders and unbalanced links with the value chain pilot. In the C4 class, peas and faba beans are mainly exported to Asia, the Middle East and North Africa. The corresponding value chains are piloted by collectors or traders. They are based in the United Kingdom and the Baltic States (Latvia, Lithuania). Finally, within the C4 class, value chain stakeholders are generally satisfied with the way legume markets function.

\subsubsection{Focus on organic legume value chains}

As stated earlier, case studies in the $\mathrm{C} 2$ class include value chains more often dedicated to feed, except the TU6 case study on lentils and the AC1 case study on organic legumes. The latter belongs to the $\mathrm{C} 2$ class because, like most of the other case studies, it was launched by a processor (here Nutrinat), it is based in France, and the stakeholders interviewed were not satisfied with the way the legume markets function. The second organic case study (LF2) in the C2 class is the faba bean value chain in Denmark, which was launched by the research and development institute SEGES. Like the other case studies in the C2 class, this chain is dedicated to feed and develops export activities, and the stakeholders interviewed said they were dissatisfied with the way the legumes markets functioned. Like in the AC1 case study, the main reason for their dissatisfaction was that their legumes activities face competition from cheaper imports.

Like most of the case studies in the $\mathrm{C} 3$ class, the two organic case studies (FI1 on soybeans in Switzerland and SU2 on mixed species in Italy) are dedicated to food and characterized by efficient information-sharing between stakeholders along the 
value chains. In addition, public support has a significant role in building the value chains. Unlike most of the case studies in the C3 class (including the FI1 case study), the value chain in the SU2 case study was not launched by extension services, but by a farmers' network. Nevertheless, in both situations, great attention is given to supporting farmers in their production and sales activities within value chains.

Finally, like all case studies in the C1 class, the TU5 organic case study on mixed species in France is dedicated to both feed and food and was launched by a downstream stakeholder (here a collector, CAVAC). While perceptions of value chain functioning differ across stakeholders in these case studies, there seems to be a consensus on inefficient information-sharing along the value chains, according to the stakeholders interviewed in most of the case studies in the $\mathrm{C} 1$ class, including the TU5 case study.

\subsubsection{Lessons from organic value chain analysis}

The results of the multidimensional factor analysis of the organic case studies provide two main lessons in understanding the characteristics of organic value chains in the EU. They also provide the conditions for the success of organic value chains in the EU.

\section{- On the general characteristics of organic value chains:}

Focusing specifically on the legume species processed in the value chain and the actor initiating its launch, our case studies show that when an organic value chain is dedicated to a single legume species, it has been launched by a research and development institute. This is the case for the two value chains involving organic soybeans (FI1) and organic faba beans (LF2). This appears to stem from a desire to develop organic farming to help reduce dependency on imports. The successful implementation of the crop is thus the prime objective of the research and development institute, which works closely with farmers. On the contrary, value chains that work on a mix of species have been launched by another type of actor, further downstream in the value chain. This is the case for the three value chains launched by the collector (TU5), by a farmers' organization (SU2), and by a processor (AC1). This appears to be justified by a desire to first meet demand on the organic market for these different legume species.

Thus, there are two opposing rationales regarding the primary objective of a value chain, which influences the type of actor initiating its launch:

- When the value chain aims to meet the organic market demand first, it is market-driven and launched by a more downstream stakeholder in the value chain, with a multispecies approach.

- When it first addresses the ambition to develop organic farming on a given territory, the value chain is productiondriven and launched by a research and development organization, with a single-species approach.

- On the success conditions of organic value chains:

It is interesting to note that the two organic case studies piloted by research and development institutes -in other words, the two production-driven value chains - belong to the two opposite classes $\mathrm{C} 2$ and $\mathrm{C} 3$, according to the results of the multidimensional factor analysis. While the FI1 case study on organic soybean in Switzerland corresponds to the type of recent value chain for human food and is characterized by efficient information-sharing between actors, the LF2 case study on organic faba beans in Denmark corresponds to the relatively older type of value chain for animal feed and is characterized by a certain dissatisfaction among the actors with the markets. The main reason why the stakeholders appear to perceive the FI1 value chain as more satisfactory is, in our opinion, the fact that the research and development organization FiBL works closely with all of the links in the value chain, i.e. the collector and the processor. The entire value chain is involved in the FiBL project to ensure that production is fully valued within the value chain. In the LF2 case study, it seems that stakeholders currently face a difficult situation in which organic faba bean production is higher than demand from the Danish feed industry. They are therefore looking for other opportunities (human food, exports). Moreover, while farmers involved in the organic soybean value chain in Switzerland receive public support, this is not the case for Danish organic faba beans farmers (legumes are not concerned by the EFA by decision of the Danish government).

Thus, two crucial success conditions for these productionoriented organic value chains are:

- The full integration of actors downstream in the value chains in the organic crop development project.

- The existence of public aid to farmers to support organic farming.

It is also interesting to note that the three case studies dealing with a mix of organic legume species (AC1, TU5, SU2) - in other words, the three market-driven value chains belong to three different classes, according to the results of the multidimensional factor analysis. Launched by three different types of actor, they also have their own development rationale. Moreover, only the Italian SU2 case study is marked by positive stakeholder perceptions, while the French TU5 and AC1 case studies are marked by negative stakeholder perceptions.

To meet the growing demand for organic products, these case studies show three various ways of organizing value chains. In the AC1 value chain, Nutrinat, the processor that launched the value chain, works closely with the cooperative Qualisol to ensure the bulk of its supply of organic pulses. As it exclusively uses French organic species to produce its dishes, Nutrinat does not import organic legumes. A certain dissatisfaction with the functioning of the markets is felt among the stakeholders due to competition from imports and the lack of clear market regulation. In the TU5 value chain, CAVAC, the cooperative that launched this organic value chain for both food and feed, works in an integrated way with other units of the CAVAC Group to meet the demand for organic food and feed. It relies on imports - though at a very low level due to the low availability of farmers' organic production. And stakeholders are generally dissatisfied with the functioning of markets and public policies, due to a lack of support for organic agriculture and the low competitiveness of products compared to imports. Finally, in the SU2 value chain, Floriddia Farm, the producer organization that launched the value chain, links 
farmers supplying organic legumes with downstream actors through short circuits (local restaurants, direct sales to consumers). The value chain does not develop import activities, as its primary objective is to develop local products. The short food supply chain would explain the efficient sharing of information between stakeholders and their overall satisfaction with the functioning of markets and the value chain.

Thus, there are two crucial success conditions for these market-oriented organic value chains:

- Once again, close collaboration between stakeholders along the value chain is an essential condition for stakeholders' satisfaction with the functioning of the value chain and markets, namely, to collectively address competitiveness issues regarding imports.

- Giving farmers a significant role in the value chain development project is an essential success condition in the value chain, precisely to ensure a reliable supply for downstream stakeholders.

\section{Conclusion}

The legume value chains analysis conducted in the LegValue project provides interesting findings on the characteristics of legume value chains in the EU, and more precisely organic legume value chains. The analysis does not claim to be exhaustive. Instead, it aims to illustrate the diversity of legume value chains and to identify their success conditions in the EU from a limited sample of case studies based on legume value chains in the ten countries participating in the LegValue project. Indeed, given the growing demand for legumes in the EU, the legume sector faces a double challenge: to increase EU production and to build value chains capable of meeting the needs of EU populations to reduce dependency on imports (Watson et al., 2017).

Regarding organic legume value chains, the analysis of the five organic case studies highlights two types of value chain characterized by the type of stakeholder initiating the value chain; the first objective of the value chain according to this key stakeholder; and the type of legume species involved. Thus, the first type of value chain is launched by a research and development organization with a single species approach. This first type of value chain is production-oriented. The second one is launched by a stakeholder further downstream in the value chain with a multi-species approach. This type of value chain is market-oriented. The analysis of the success conditions of the five organic legume value chains shows that the value chain efficiency depends on the ability of the stakeholder that initiated its launch to work closely with all stakeholders along the value chain. In other words, if the value chain is production-oriented, the upstream actor at the initiative of launching the value chain (research and development organization or producer organization) should not neglect outlet issues. Similarly, if the value chain is market-oriented, the downstream stakeholder at the initiative of launching the value chain (collector, processor, producer organization) should pay attention to legume supply issues. The longer the value chain, the more challenging it is for the stakeholders to coordinate along it. However, it is necessary to do so through means and tools, like for example setting up a value chain development project, implementing contracting practices, developing production support programmes (on technical assistance, financial supports, etc.) as well as market support programmes (on information, regulation, facilitators, etc.).

Acknowledgments. The H2020 LegValue project received funding from the EU's Horizon 2020 research and innovation programme under grant agreement $\mathrm{N}^{\mathrm{O}} 727672$. We thank all of the project partners who conducted the survey on value chains, as well as the value chain stakeholders who accepted to participate in the survey.

\section{References}

Agence Bio. 2019. Les grandes cultures bio dans l'Union Européenne, Les carnets internationaux de l'Agence Bio. https://www.agencebio.org/2019/11/21/publication-grandes-cul tures-bio-dans-lue/.

Agrosynergie. 2018. Market Developments and Policy Evaluation Aspects of the Plant Protein Sector in the EU. Final Report. European Commission. https://ec.europa.eu/agriculture/externalstudies/plant-proteinreport-nov-2018_en.

Cholez C. 2019. Structures de gouvernance des transactions et dynamique des connaissances inter-firmes dans la création de filière : application aux contrats de production dans le secteur des grandes cultures en France. Doctorat d'économie de l'Université de Toulouse, École Doctorale TESC, 332 p.

European Commission. 2019. EU agricultural outlookfor markets and income 2019-2030. Brussels: European Commission, DG Agriculture and Rural Development. https://ec.europa.eu/info/ news/eu-agricultural-outlook-2019-2030-societal-demands-driv ing-food-market-developments-combining-affordability-sustain ability-and-convenience-2019-dec-10_en\#moreinformation.

European Commission. 2020. Farm to Fork Strategy. For a fair, healthy and environmentally friendly food-system. Brussels: DG Health and Food Safety. https://ec.europa.eu/food/farm2fork_en.

Husson F, Lê S, Pagès J. 2017. Exploratory Multivariate Analysis by Example Using R, 2nd edition. CRC/Press, $230 \mathrm{p}$.

Husson F, Josse J. 2014. Multiple Correspondence Analysis. In: Blasius J, Greenacre M, eds. Visual Verbal Data: 165-184.

Kezeya Sepngang B, Muel F, et al. 2020. Report on legume markets in the EU. Forschungsberichte des Fachbereichs Agrarwirtschaft. Soest. $\mathrm{Nr}$ 50. http://www.legvalue.eu/publications/report-onmarkets-in-the-eu/.

Magrini MB, Anton M, Cholez C, et al. 2016. Why are grain-pulses rarely present in cropping systems despite their environmental and nutritional benefits? Analyzing lock-in in the French agrifood system. Ecol Econ 126: 152-162. https://doi.org/0.1016/j. ecolecon.2016.03.024.

MAPAMA. 2016. Caracterización del sector de la producción ecológica español entérminos de valor y mercado (2015). Madrid.

Meynard JM, Messéan A, Charlier A, et al. 2013. Freins et leviers à la diversification des cultures : étude au niveau des exploitations agricoles et des filières. OCL 20(4). https://doi.org/10.1051/ocl/ 2013007.

Smadja T, Magrini MB, Muel F. 2019. Report on legume-based value chains sector diagnosis. LegValue H2020 project.

Voisin AS, Gueguen J, Huyghe C, et al. 2014. Legumes for feed, food, biomaterials and bioenergy in Europe: A review. Agron Sustain Dev 34: 361-380. https://doi.org/10.1007/s13593-013-0189-y. 
Watson CA, Reckling M, Preissel S, et al. 2017. Grain legume production and use in European agricultural systems. Adv Agron 144: 235-303.

Willer H, Schlatter B, Travnicek J, Kemper L, Lernoud J, eds. 2020. The World of Organic Agriculture. Statistics and Emerging Trends 2020. Bonn: Research Institute of Organic Agriculture
(FiBL), Frick, and IFOAM - Organics International. https://www. organic-world.net/yearbook/yearbook-2020/pdf.html.

Zander P, Amjath-Babu T, Preissel S, et al. 2016. Grain legume decline and potential recovery in European agriculture: A review. Agron Sustain Develop 36(2): 26. Springer Verlag/EDP Sciences/INRA. https://doi. org/10.1007/s13593-016-0365-y. Available from hal-01532455.

Cite this article as: Smadja T, Muel F. 2021. Analysis of EU legume value chains from the H2020 LegValue project: What insights for organic value chains?. OCL 28: 15 . 